\title{
SENTENÇAS JUDICIAIS NO PROCESSO PENAL CONDENATÓRIO: ANÁliSE À LUZ DA CLASSIFICAÇÃo TERNÁRIA DA TUTELA JURISDICIONAL COGNITIVA
}

Thadeu Augimeri de Goes

$\operatorname{Lima}^{1}$

\section{Resumo}

O presente artigo analisa a tipologia de sentenças judiciais no processo penal de conhecimento condenatório brasileiro, à luz da classificação ternária da tutela jurisdicional cognitiva, buscando identificar a real natureza jurídica da tutela conferida por cada uma. Parte de referenciais teóricos inspirados na Teoria Geral do Processo e utiliza preferencialmente os métodos dialético, sistemático, indutivo e dedutivo. Inicia abordando a tutela jurisdicional e sua classificação como temas de Teoria Geral do Processo. Na sequência, examina a tutela jurisdicional cognitiva e sua manifestação no processo penal de conhecimento. Continua com a análise das decisões judiciais definidas como sentenças previstas na estrutura do processo penal condenatório. Encerra com as principais conclusões obtidas no estudo da matéria.

Palavras-Chave: Tutela jurisdicional. Classificação. Tutela cognitiva. Processo penal condenatório. Sentenças judiciais.

\section{INTRODUÇÃO}

A tutela jurisdicional consiste em tema que, notadamente nas últimas duas décadas, após o advento da Constituição da República de 1988 e da promessa de justiça para todos contemplada no seu art. $5^{\circ}$, inc. XXXV, veio ganhando destaque na doutrina pátria como um dos mais importantes do Direito Processual, em especial no bojo do Processo Civil, no qual os anseios e clamores pela efetividade do processo mais pulsaram e fizeram renovar a atenção ao instituto.

Com efeito, percebeu-se que o acesso à ordem jurídica justa não se resume a oportunizar uma tendencialmente irrestrita dedução de pretensões perante o Poder Judiciário,

\footnotetext{
${ }^{1}$ Doutorando em Direito Processual pela Faculdade de Direito do Largo de São Francisco, da Universidade de São Paulo (USP). Membro-fundador, vice-presidente e pesquisador do Instituto Ratio Juris - Pesquisa, Publicações e Ensino Interdisciplinares em Direito e Ciências Afins. Coordenador e professor do curso de pós-graduação, nível de especialização, em "Ministério Público e Estado Democrático de Direito", da Fundação Escola do Ministério Público do Estado do Paraná (FEMPAR), unidade de Londrina. E-mail: tagl@bol.com.br
} 
mostrando-se de igual relevância a preocupação quantitativa e qualitativa com os outputs do sistema processual civil. Diante da constatação do exponencial crescimento do número de demandas, do tumultuado e assoberbado cotidiano forense e da frustração dos efeitos almejados pelos mecanismos processuais, viu-se que, a par de garantir o ingresso em juízo, é imprescindível outorgar àquele que se socorre dos órgãos judiciais a solução adequada, tempestiva e útil ao seu caso. Assim, houve inegável influência da realidade prática sobre o desenvolvimento dogmático, compelindo-o a repensar institutos de modo a adaptá-los às necessidades concretas. Nesse contexto, sobressaiu a tutela jurisdicional, que ganhou novíssimos e respeitáveis contornos e alcance.

Cumpre registrar que o tema em apreço, repita-se, a tutela jurisdicional, não é exclusividade do Processo Civil, encontrando guarida também no Processo Penal. Todavia, como regra, o seu estudo aqui tem sido bem mais superficial, indo nada ou pouco além das singelas noções propedêuticas, sem maiores problematizações diante das características próprias que marcam este ramo do Direito Processual.

Dentre os variados aspectos do fenômeno dignos de investigação, um bastante interessante, mormente sob a perspectiva científica, diz respeito à análise da tipologia de sentenças judiciais na estrutura do processo penal de conhecimento condenatório brasileiro, à luz da classificação da tutela jurisdicional cognitiva, buscando identificar a real natureza jurídica da tutela conferida por cada uma, tarefa a que se propõe o presente artigo.

O trabalho parte de referenciais teóricos inspirados na vertente epistêmicometodológica conhecida como Teoria Geral do Processo e utiliza preferencialmente os métodos dialético, sistemático, indutivo e dedutivo. O método dialético se presta, aqui, à confrontação e à síntese dos argumentos de relevo, ao passo que o método sistemático é empregado para organizar e aplicar as categorias lógico-jurídicas pertinentes. Ao seu turno, os métodos indutivo e dedutivo servem à verificação do enquadramento dos atos decisórios processuais penais selecionados em ditas categorias.

$\mathrm{O}$ artigo inicia abordando a tutela jurisdicional e sua classificação como temas de Teoria Geral do Processo. Na sequência, examina a tutela jurisdicional cognitiva e sua manifestação no processo penal de conhecimento. Continua com a análise das decisões definidas como sentenças previstas na estrutura do processo penal condenatório em primeiro grau de jurisdição, quais sejam: 1) sentença de impronúncia; 2) sentença absolutória própria; 3) sentença absolutória imprópria; e 4) sentença condenatória. Finalmente, encerra com as principais conclusões obtidas no estudo da matéria. 


\section{TUTELA JURISDICIONAL E SUA CLASSIFICAÇÃO: TEMAS DE TEORIA GERAL DO PROCESSO}

A expressão tutela jurisdicional, sob o aspecto conceitual e em acepção compatível com a promessa constitucional de proteção judicial efetiva (MENDES, 2010, p. 591), há que ser tomada como a proteção real e concreta outorgada por meio da atividade jurisdicional a situações jurídicas subjetivas consideradas relevantes pelo ordenamento jurídico, seja por estarem sujeitas a palpável risco, seja por corresponderem, ainda que prima facie, ao conteúdo de comandos normativos, e independentemente de guardarem natureza substancial ou processual (LIMA, 2013, p. 143-144). Vale frisar que a tutela jurisdicional não se limita a operar no plano lógico-jurídico, antes e com maior ênfase atuando no mundo empírico, no propósito de ensejar ao favorecido os resultados práticos idênticos aos ou aproximados ao máximo dos que seriam obtidos com a voluntária observância da norma pelo sujeito obrigado. Outrossim, ela não faz distinção entre meras pretensões, interesses jurídicos ou direitos definitivamente reconhecidos, de feição material ou instrumental, pondo-se a resguardá-los sempre que dotados de relevância jurídica e carentes de proteção. Tem-se destarte uma conceituação ampla do fenômeno, capaz de colocar sob sua égide toda a tipologia apresentada nas classificações doutrinárias (por exemplo, tutelas preventiva e repressiva; tutelas cognitiva, executiva e cautelar; tutelas interinal ou provisional e definitiva etc) (LIMA, 2013, p. 144).

Segundo entendemos, é do inc. XXXV (garantia da inafastabilidade do controle jurisdicional), conjugado com os incs. LIV (garantia do devido processo legal), LV (garantias do contraditório e da ampla defesa) e LXXVIII (garantias da duração razoável e da celeridade do processo), todos do art. $5^{\circ}$. da Constituição da República de 1988, que exsurge, pela via interpretativa, a norma principiológica dirigida ao legislador e ao Poder Judiciário que institui o direito público subjetivo fundamental à tutela jurisdicional qualificada pelos predicados de adequação, tempestividade e efetividade (LIMA, 2013, p. 142).

Detalhando a assertiva supra, trata-se de um princípio jurídico, eis que sobrelevam o seu caráter imediatamente finalístico e primariamente prospectivo e a pretensão de complementaridade e de parcialidade, exigindo, para sua aplicação, a avaliação da correlação entre o estado de coisas a ser promovido e os efeitos decorrentes da conduta havida como necessária à sua promoção (ÁVILA, 2009, p. 78-79). No caso, o estado de coisas a ser promovido é a aspiração axiológica do acesso à ordem jurídica justa, o que evidencia o íntimo liame da referida tutela jurisdicional qualificada com a garantia do devido processo legal, contemporaneamente traduzida como direito ao processo justo (CAMBI, 2001, p. 111; NERY 
JR., 2002, p. 32). Ademais, tal princípio se impõe ao legislador, cobrando dele a construção e o desenvolvimento de formas procedimentais e de técnicas processuais aderentes às necessidades do direito material (adequadas, tempestivas e efetivas), bem como aos órgãos jurisdicionais, exigindo que, nas situações concretas sob sua apreciação, empreguem aquelas que se mostrarem melhores e mais indicadas para conferir cabal proteção ao interesse ou direito substancial em tese ameaçado ou lesionado, inclusive fazendo as pertinentes adaptações, sem prejuízo de, na ausência de lei expressa, suprirem a omissão impeditiva dessa proteção (MARINONI, 2008, p. 206-207; CAMBI, 2009, p. 222).

Destarte, no atual panorama constitucional, a tutela jurisdicional não pode mais ser caracterizada restritivamente como proteção dada somente a quem tem razão no plano do direito material ${ }^{2}$, devendo ser compreendida em sentido extensivo, que abarque todas as modalidades e espécies de tutelas passíveis de serem concedidas pelo Estado-juiz (LIMA, 2013, p. 143). Luiz Guilherme Marinoni (1996, p. 123) adverte que quem parte da premissa de que só possui direito à adequada tutela jurisdicional aquele que tem razão perante o ordenamento substancial não consegue dar a abrangência necessária à inafastabilidade do controle jurisdicional, que garante a todos, estejam ou não amparados no plano material, aquela tutela. O direito de ação - completa o processualista paranaense - tem como corolário o direito ao procedimento adequado e à tutela do direito afirmado, pouco importando se aquele que propõe a demanda ostenta, verdadeiramente, o direito material.

Tamanha é a importância da tutela jurisdicional no hodierno contexto da ciência processual que se chega a preconizar o seu estudo como instituto processual autônomo, quiçá passando a compor o próprio quadro dos institutos fundamentais no que tange ao ramo específico do Processo Civil. ${ }^{3}$ Todavia, preferimos enxergar o direito público subjetivo fundamental a ela (qualificada pela adequação, pela tempestividade e pela efetividade) como elemento, aspecto, extensão, modalidade ou prolongamento dos próprios direitos fundamentais de ação e de defesa, nos exatos moldes dos direitos processuais à prova e ao recurso (LIMA, 2013, p. 144). ${ }^{4}$ De fato, a proteção pelo Poder Judiciário pode ser dada tanto ao autor quanto ao réu, o que se explica por conta do paralelismo usualmente visto entre a ação e a defesa, unidas

\footnotetext{
${ }^{2}$ Neste sentido restritivo, cf. LIEBMAN, 1980, v. 1, p. 129; DINAMARCO, 1996, p. 29; e BEDAQUE, 1997, p. 24.

${ }^{3}$ Sustentando a perspectiva do estudo da tutela jurisdicional como instituto processual autônomo, v. DINAMARCO, 1996, p. 19-20; e BUENO, 2010, v. 1, p. 309. Defendendo a sua inserção no quadro dos institutos fundamentais do Direito Processual Civil, cf. SICA, 2013, p. 445-448.

${ }^{4}$ Sobre o direito à prova como aspecto ou elemento dos direitos de ação e de defesa, cf. GOMES FILHO, 1997, p. 84-85; e CAMBI, 2001, p. 112-113, 123-124. De igual modo quanto ao direito de recorrer, v. GRINOVER; FERNANDES; GOMES FILHO, 1999b, p. 32; e MORAES, 2000, p. 35-37.
} 
pelo processo, definido como procedimento (adequado) em contraditório. ${ }^{5}$ Todavia, uma vez que tal paralelismo não significa plena identidade e nem tem caráter absoluto ${ }^{6}$, a tutela jurisdicional apresenta mais intensidade e maior variabilidade quando ligada às posições ativas inerentes ao exercício da ação, razão por que, inclusive, destacando o seu nexo instrumental, serve-lhe de critério classificatório (LIMA, 2013, p. 144-145).

Note-se que a tutela jurisdicional, quando conferida ao réu que se manteve em postura exclusivamente defensiva no curso procedimental, resume-se ao juízo de inadmissibilidade, com a extinção do processo sem resolução de mérito ${ }^{7}$, ou a uma sentença de improcedência que muitas vezes sequer declara peremptoriamente a inexistência da relação jurídica aventada pelo autor como fundamento de sua pretensão, limitando-se a reconhecer a insuficiência probatória da parte do demandante. Diferentes, ao seu turno, são as hipóteses nas quais o demandado assume postura ativa e exerce também o direito de ação no mesmo processo, manejando reconvenção ou pedido contraposto, ou das chamadas ações dúplices, em todas elas podendo, desde que obtenha êxito, beneficiar-se das acrescidas intensidade e variabilidade adrede ressaltadas. $^{8}$

Várias são as classificações possíveis da tutela juridicional, dependentes do critério eleito pelo observador para estabelecer o discrímen entre umas e outras modalidades e espécies verificadas na realidade. A coerência lógica do labor classificatório radica fundamentalmente na acurada fixação desse critério discriminatório e na correta identificação, a partir dele, das características que assemelham e das que apartam aquelas modalidades e espécies. A utilidade prática da classificação, por outro lado, em especial para uma ciência social aplicada como é a ciência jurídica, reside principalmente na sua aptidão para separar os fenômenos investigados de modo a enquadrá-los em regimes jurídicos que facilitem a dedução das suas consequências normativas. Sob o ponto de vista estritamente processual, a mais tradicional e reconhecidamente importante classificação doutrinária da tutela jurisdicional adota como

\footnotetext{
${ }^{5}$ Daí porque, como já adiantamos, visualizamos a norma principiológica que dá suporte ao direito à tutela jurisdicional qualificada a partir da conjugação dos incs. XXXV, LIV, LV e LXXVIII do art. $5^{\circ}$ da CF/1988. ${ }^{6}$ Por exemplo, no processo penal condenatório tal paralelismo é severamente mitigado, uma vez que só o Estado e o ofendido podem exercer o direito de ação, ao passo que o suspeito/imputado deve sempre figurar na posição de acusado, cf. FERNANDES, 2005, p. 283.

${ }^{7}$ Mesmo Cândido Dinamarco (1996, p. 29) entende que, havendo extinção do processo sem resolução do mérito, presta-se tutela jurisdicional ao demandado, conquanto de menor intensidade, liberando-o do vínculo que a própria pendência processual representa. Em orientação similar, Susana Henriques da Costa (2005, p. 123-137) inclusive defende a visão das condições da ação e da carência de ação como técnica processual diferenciada voltada a conferir de forma imediata, ou mais breve possível, a tutela jurisdicional em favor do réu contra o exercício abusivo do direito de ação pelo autor.

${ }^{8}$ Em sentido oposto, sustentando a perfeita simetria entre os direitos de ação e de defesa, e por conseguinte atribuindo ao último eficácia bem mais ampla, praticamente idêntica à passível de ser obtida com o exercício da ação, v. SICA, 2011.
} 
critério a natureza da atividade preponderantemente desempenhada pelo juiz no processo, distinguindo-a em três categorias: tutela jurisdicional cognitiva, tutela jurisdicional executiva e tutela jurisdicional cautelar (CINTRA; GRINOVER; DINAMARCO, 2010, p. 326 ss; BEDAQUE, 2007, p. 511, 521-522; CÂMARA, 2008, v. 1, p. 82-83, 214-215; TUCCI, 2002, p. $102-108,233-234){ }^{9}$

De acordo com prestigiadas lições, a tutela jurisdicional cognitiva se volta precipuamente à formulação da norma jurídica concreta definidora da situação controvertida submetida à apreciação do Poder Judiciário, ao passo que a tutela jurisdicional executiva se volta à atuação prática daquela norma jurídica concreta (CINTRA; GRINOVER; DINAMARCO, 2010, p. 328, 339; BARBOSA MOREIRA, 2010, p. 3). Por fim, a tutela jurisdicional cautelar se destina a assegurar o resultado prático útil de uma ou outra das citadas atividades, conservando diretamente o(s) interesse(s) objeto(s) de disputa judicial (cautela final) ou o regular desenvolvimento do processo (cautela instrumental) contra perigos que possam perturbá-los. Não se olvide, ademais, que esta última modalidade, contemporaneamente, tem sido inserida em uma categoria maior denominada tutela de urgência, abrangente das providências destinadas a afastar os riscos à fruição do direito material, seja com a sua pura e simples assecuração (tutela urgente cautelar), seja com o seu provisório adiantamento a uma das partes (tutela urgente satisfativa antecipatória, ou simplesmente tutela antecipada) (CINTRA; GRINOVER; DINAMARCO, 2010, p. 344-348; CÂMARA, 2008, v. 1, p. 83-87, 214-215; MARINONI, 2004, p. 82-86; BEDAQUE, 2007, p. 511; TUCCI, 2002, p. 107, 234).

$\mathrm{Na}$ doutrina brasileira, a ideia de tutela jurisdicional e o esquema classificatório em tela são amplamente acolhidos não só no âmbito do Processo Civil, como também no do Processo Penal, o que permite concluir tratarem-se de temas que verdadeiramente se encontram sob os auspícios da Teoria Geral do Processo. ${ }^{10}$

\footnotetext{
${ }^{9}$ Para classificações da tutela jurisdicional a partir de criterios oriundos das necessidades do direito material, v. MARINONI, 2004, p. 191 ss.

${ }^{10}$ Cândido Rangel Dinamarco (2005, p. 69) conceitua a Teoria Geral do Processo como "um sistema de conceitos e princípios elevados ao grau máximo de generalização útil e condensados indutivamente a partir do confronto dos diversos ramos do direito processual". O intuito unificador e de evidente inspiração constitucional por ela propugnado, com vistas a elaborar noções comuns aplicáveis às vertentes da ciência processual, trouxe uma interconexidade entre todas, com consequente influência de uma sobre a outra, sempre buscando pensar a melhoria do sistema processual no enfoque de sua efetividade e, no caso do processo judicial, da justiça na prestação jurisdicional. Apesar de autorizadas vozes que a combatem, vindas sobretudo do Processo Penal, trata-se de perspectiva epistêmico-metodológica de extrema importância reflexiva, que não pretende retirar de cada ramo da ciência do Direito Processual a sua autonomia ou impor respostas idênticas para os problemas diversos que enfrentam, pois, como frisa o próprio Dinamarco (2005, p. 89), unidade de método não implica homogeneidade de soluções.
} 
A propósito, vale trazer à colação o magistério de Rogério Lauria Tucci et alii (2004, p. 111-112):

\begin{abstract}
A jurisdição é o poder-dever de realizar a justiça estatal, ou a atividade dos juízes e tribunais no exercício da função de garantir o respeito à ordem jurídica e, quando violada, restaurá-la, para, assim, assegurar a paz social mediante a pacificação de conflitos e a asseguração da liberdade do ser humano, tudo em prol do bem comum.

Como poder-dever, é a jurisdição visualizada em potência; como atividade, é ela visualizada em ato, conforme a lição de Sérgio Marcos de Moraes Pitombo, na esteira de Joaquim Canuto Mendes de Almeida.

A esse poder corresponde a função de tutela jurisdicional, exercida em atividade pelos órgãos do Poder Judiciário, associada ao dever de prestação jurisdicional, cujo correlato é o direito de acesso à justiça.

Tal dever se desdobra, conforme deva-se reconhecer (ações declaratórias, constitutivas e condenatórias), satisfazer (ação de execução) ou assegurar (no âmbito extrapenal, ação cautelar, e, na esfera penal, medidas cautelares) o direito material violado ou ameaçado. ${ }^{11}$
\end{abstract}

Com efeito, costuma-se aceitar sem problema a existência, na seara processual penal, de módulos processuais inteiramente estruturados para a prestação das tutelas jurisdicionais cognitiva e executiva, isto é, de processos de conhecimento ou cognição e de execução. Todavia, ante a sistemática legal vigente, não se admite a autonomia de um processo penal cautelar, podendo-se falar na prestação da tutela jurisdicional cautelar somente através de medidas cautelares processuais penais (TUCCI, 2002, p. 102-108; JARDIM, 2005, p. 37; GRECO FILHO, 1998, p. 115; BADARÓ, 2012, p. 117, 709-710). ${ }^{12}$ Helio Tornaghi (1978, v. 3, p. 3-6) se vale dos termos providências processuais assecuratórias, providências acautelatórias, tutela previdencial e proteção acauteladora para se referir a elas e aduz que, ao contrário do que acontece no Processo Civil, parece razoável considerá-las como meros incidentes no Processo Penal pátrio. ${ }^{13}$

\footnotetext{
${ }^{11}$ Acerca do tema, v. ainda MARQUES, 1965 , v. 1, p. 321-328, 409-413; MARQUES, 1965 , v. 4, p. 5 ss; TUCCI, 2002, p. 102-108; JARDIM, 2005, p. 35-38; MACHADO, 2009, p. 117; GOMES FILHO, 2011, p. 15-51; MORAES, 2010, p. 370-399; e KARAM, 2009, p. 1-23.

${ }^{12}$ Sobre a execução penal e sua autonomia como espécie de processo jurisdicional, v. BENETI, 1996; MIRABETE, 1993, p. 28-32; e CARVALHO, 2007, p. 307 ss.

${ }^{13}$ Segundo Antonio Scarance Fernandes (2005, p. 312-313), as medidas cautelares no sistema processual penal brasileiro podem ser classificadas em medidas cautelares pessoais, relacionadas com o suspeito/imputado/acusado; medidas cautelares de natureza civil (reais), relacionadas com a reparação do dano; e medidas cautelares relativas à prova, tanto para efeito penal como para efeito civil. Para um quadro geral das medidas cautelares previstas no Processo Penal italiano, v. CORDERO, 2006, p. 467 ss. Sobre as medidas cautelares pessoais previstas no nosso CPP, após a reforma operada pela Lei 12.403/2011, inclusive tecendo considerações sobre a distinção entre a tutela cautelar e a tutela antecipada, como espécies do gênero tutela de urgência, v. BADARÓ, 2011, p. 205-297. Outrossim, no grupo das medidas cautelares relativas à prova se enquadram os chamados meios de pesquisa, de investigação ou de obtenção de prova, cf. FERNANDES, 2011, p. 24-26. Tratando-se da interceptação de comunicações telefônicas, o provimento que a autoriza tem nítida natureza cautelar, visando a assegurar as provas pela fixação dos fatos assim como se apresentam no momento da conversa. Por isso mesmo, a operação só pode ser autorizada quando presentes os requisitos que justificam as medidas cautelares, devendo ainda ser a ordem motivada, cf. GRINOVER;
} vol.09, nº 03, Rio de Janeiro, 2016. pp. 
Tecidas essas ponderações proemiais, e na sequência planejada para o enfrentamento do objeto principal do presente trabalho, podemos passar ao exame específico da tutela jurisdicional cognitiva e de sua manifestação no módulo processual penal de conhecimento.

\section{TUTELA COGNITIVA E PROCESSO PENAL DE CONHECIMENTO}

Retomando o que dissemos alhures, a tutela jurisdicional cognitiva se volta precipuamente à formulação da norma jurídica concreta definidora da situação controvertida submetida à apreciação do Poder Judiciário, envolvendo uma atividade predominantemente lógica e retrospectiva de reconstrução histórica dos fatos relevantes e de enquadramento deles em esquemas normativos. Outrossim, como é notório, os provimentos jurisdicionais inerentes a tal modalidade de tutela costumam ser alocados pelos estudiosos em subgrupos, de acordo com as específicas finalidades instrumentais e eficácias que ostentam diante da crise substancial cuja resolução se postula.

Destarte, divide-se a doutrina processual entre as chamadas classificações ternária e quinária da tutela cognitiva. A classificação ternária, como é fácil inferir por sua própria nomenclatura, sustenta que a tutela cognitiva se desdobra em três espécies, quais sejam, a meramente declaratória, a constitutiva e a condenatória. A classificação quinária, a seu turno, acrescenta àquelas três espécies outras duas: a mandamental e a executiva "lato sensu" (CINTRA; GRINOVER; DINAMARCO, 2010, p. 328-332; BEDAQUE, 2007, p. 513-514; TESHEINER, 1993, p. 144-154; MARINONI, 2004, p. 86 ss; RODRIGUES; LAMY, 2012, p. 94-97). Iniciemos pela classificação ternária.

Assevera-se que a tutela meramente declaratória (positiva ou negativa) tem por objetivo solucionar uma crise de certeza, promovendo o acertamento de uma relação jurídica controvertida ao afirmar a sua existência ou inexistência, a sua validade ou invalidade, a sua eficácia ou ineficácia ou, ainda, o seu modo de ser. Excepcionalmente, a lei pode prever a possibilidade de declaração da existência ou inexistência de um fato (LOPES, 2002, p. 80 ss; CINTRA; GRINOVER; DINAMARCO, 2010, p. 329-330; BEDAQUE, 2007, p. 522-523; TESHEINER, 1993, p. 144-145; RODRIGUES; LAMY, 2012, p. 95-96).

A tutela constitutiva (positiva ou negativa), de seu lado, contém também o elemento declaratório (positivo ou negativo) ínsito em todas as espécies de tutela cognitiva, porém tem por escopo solucionar uma crise de estabilidade de um dado status jurídico e atua prospectivamente, promovendo a criação, a modificação ou a extinção de uma relação jurídica

FERNANDES; GOMES FILHO, 1999a, p. 174. Sobre os meios de pesquisa, de investigação ou de obtenção vol.09, nº 03, Rio de Janeiro, 2016. pp. 
(CINTRA; GRINOVER; DINAMARCO, 2010, p. 331; BEDAQUE, 2007, p. 523-526; TESHEINER, 1993, p. 145-148; RODRIGUES; LAMY, 2012, p. 96).

Já a tutela condenatória intenta dar cabo, em linhas gerais, de uma crise de observância da norma, oriunda da violação de um mandamento geral ou do descumprimento de um dever ou de uma obrigação específicos. Cabe ressaltar que grassa certa polêmica acerca do significado mesmo de "condenação". De fato, o termo é usualmente tomado nas acepções de comando dirigido ao devedor para cumprir a obrigação; comando aos órgãos da execução para realizá-la; constituição do poder de dar início à execução em favor do titular do direito, com a correlata criação do estado de sujeição do réu; ou afirmação da existência do direito e de sua violação e aplicação de preceito processual sancionador que possibilita o acesso à via da execução forçada (BEDAQUE, 2007, p. 527-528 e nota 34; CINTRA; GRINOVER; DINAMARCO, 2010, p. 330; TESHEINER, 1993, p. 148-150).

Em uma perspectiva ampla, todavia, parece que essas acepções, ao invés de excludentes, são complementares e desvelam as características próprias da tutela condenatória quanto ao seu conteúdo, a sua forma e a sua eficácia. Assim, pode-se dizer que o conteúdo da condenação consiste no reconhecimento da infração a uma norma substancial proibitiva ou preceptiva, ou seja, de um ilícito (penal ou extrapenal), e na fixação concreta das consequências jurídicas que o ordenamento lhe comina, isto é, de uma sanção igualmente substancial (penal ou extrapenal). No aspecto formal, o comando judicial emergente da tutela condenatória se traduz em um preceito processual sancionador que absorve e cristaliza aquela sanção material e, simultaneamente, constitui o título executivo, legitimador do emprego da execução forçada para a sua realização. Finalmente, no plano eficacial, a condenação autoriza e regula a subsequente invasão da esfera jurídica do réu, a prática de atos de coerção e a privação ou restrição de determinados bens jurídicos dele - via de regra, a liberdade ou o patrimônio para dar efetividade à sanção aplicada, nos casos em que o condenado não a cumpre ou não a pode cumprir de modo voluntário - aqui, como soi acontecer na esfera penal.

Partindo à classificação quinária, os seus adeptos habitualmente acusam a classificação ternária de ser insuficiente, pretendendo por isso lhe acrescer outras duas espécies de tutelas cognitivas, nomeadamente a mandamental e a executiva lato sensu. Segundo eles, a peculiaridade da tutela mandamental reside notadamente na ordem que caracteriza o teor do comando judicial exarado e que, a depender do caso, pode ser dirigida ao próprio réu ou a órgão estatal diverso do Judiciário e estranho ao processo. Por outro lado, a chamada tutela

de prova no Direito Processual Penal italiano, v. TONINI, 2002, p. 242-252; e LOZZI, 2010, p. 205 ss. vol.09, n. 03, Rio de Janeiro, 2016. pp. 
executiva lato sensu - impropriamente, a juízo de boa parte da doutrina, visto que traz de plano a indagação sobre a existência de uma tutela cognitiva-executiva stricto sensu - tem por marca diferencial a independência de posterior processo executivo para que seus efeitos práticos se realizem, com a concretização deles incontinenti no mesmo processo em que proferida a decisão (TESHEINER, 1993, p. 150-154; MARINONI, 2004, p. 86 ss).

Os estreitos limites deste artigo não recomendam prolongar a digressão sobre a celeuma doutrinária em comento, razão por que desde logo consignamos nossa preferência pela classificação ternária. Com efeito, parece-nos que as assim designadas "tutelas" mandamental e executiva lato sensu não apresentam, sob o ponto de vista dogmáticoprocessual, especificidades teleológico-instrumentais e eficaciais aptas a distingui-las das tradicionalmente referidas tutelas declaratória, constitutiva e condenatória, tratando-se mais propriamente de formas ou técnicas de efetivação prática dos comandos judiciais emergentes das sentenças proferidas no processo de conhecimento, ligadas na maioria dos casos à tutela condenatória. Portanto, decorrem mais de opções político-legislativas de configuração normativa do sistema processual do que realmente de imperativos lógico-científicos. ${ }^{14}$ Tais conclusões, ademais, valem tanto para o Processo Civil quanto para o Processo Penal, resultando que a classificação ternária repousa bem posta sob a unidade epistêmicometodológica preconizada pela Teoria Geral do Processo.

Feitas essas observações, passemos ao estudo da manifestação da tutela jurisdicional cognitiva no âmbito do Direito Processual Penal, de pronto salientando que em nada se alteram a sua destinação de formular a norma jurídica concreta definidora da situação controvertida submetida à apreciação do Poder Judiciário e a sua atividade predominantemente lógica e retrospectiva de reconstrução histórica dos fatos relevantes e de enquadramento deles em esquemas normativos. A especificação concerne só a esses esquemas normativos, que correspondem a regras e princípios de Direito Penal substancial.

A norma jurídico-penal incriminadora tem natureza de proposição imperativa ou prescritiva e se endereça a todos os cidadãos genericamente considerados, através de mandados (imperativo positivo) ou proibições (imperativo negativo) implícita e previamente formulados, visto que a lei penal modernamente não contém ordem direta, mas sim vedação indireta, na qual se descreve um comportamento humano como pressuposto de uma consequência jurídica. Outrossim, o que realmente importa é o conteúdo próprio da norma, que é sempre um imperativo ou prescrição. A proposição imperativa ou prescritiva, como forma de linguagem,

\footnotetext{
${ }^{14}$ Nesse sentido, concordamos essencialmente com CINTRA; GRINOVER; DINAMARCO, 2010, p. 331 332; e BEDAQUE, 2004, p. 513-521.
} 
pode ser positiva ou negativa, segundo exprima um dever/obrigação ou uma omissão. Tendo em vista a sua natureza, violam-se uma proibição (ação) ou uma ordem/comando de agir (omissão) (PRADO, 2006, v. 1, p. 170).

Considerada como contendo implícito o preceito, a lei penal se dirige, com a sua definição do que é ilícito, a todos aqueles que estão sujeitos ao seu império. Pela sua sanção, ela se destina, em particular, aos juízes, a quem cumpre aplicá-la. Mas ainda por esta função sancionadora há que se lhe reconhecer a universalidade de destinatários, como ameaça que se direciona a todos, na prevenção geral dos fatos puníveis (BRUNO, 1959, t. 1, p. 496).

É lição corrente que, uma vez praticada a conduta prevista no tipo penal (em cujo bojo constam o preceito primário, constituído pela descrição do comportamento, e o preceito secundário, constituído pela sanção), surge para o Estado o direito (ou poder-dever) de punir, isto é, de aplicar contra o autor da infração a sanção penal. Se o Estado confere proteção a determinados bens jurídicos, que reputa relevantes ao interesse da coletividade, nada mais lógico do que reagir contra o infrator, punindo-o em conformidade com a gravidade da falta. A punição ao responsável pela lesão social, assim, representa a justa reação, em nome da defesa da ordem e da boa convivência entre os cidadãos. O chamado jus puniendi é uma manifestação da soberania estatal e, segundo Grispigni, enquadra-se na categoria dos direitos públicos subjetivos do Estado (BOSCHI, 1987, p. 16-17).

Prevendo ações e omissões contrárias à ordem jurídica, a lei penal delineia os crimes e as contravenções, fixa-lhes as penas e institutos afins e cria o direito objetivo. Este atribui ao Estado o direito subjetivo de punir os possíveis transgressores, impondo por essa forma a obediência, o respeito à mesma lei. Com a violação dela, porém, aquele direito subjetivo de punir, que indistinta e abstratamente visa aos possíveis infratores, modifica-se em relação ao real infrator da lei penal, transformando-se em um direito concreto, atual e efetivo e fazendo surgir a punibilidade, que, posta em movimento pelo aparato persecutório estatal, dá margem à comumente denominada pretensão punitiva (MARQUES, 1961, v. 2, p. 112-113; ROMEIRO, 1978, p. 3; PRADO, 2006, v. 1, p. 705). ${ }^{15}$ A punibilidade e a pretensão punitiva são, em nossa ótica, aspectos do mesmo fenômeno jurídico-substancial, encarado, respectivamente, de formas estática e dinâmica.

\footnotetext{
${ }^{15}$ Registre-se, contudo, a posição divergente de James Goldschmidt (2002, p. 28-29), para quem, desde que a pena pública substituiu a composição privada e, consequentemente, o Processo Penal se destacou do Processo Civil, o primeiro requer suas próprias categorias, adequadas à essência de seu objeto, o direito do Estado de punir. Como a pena é uma manifestação da justiça distributiva, corresponde o jus puniendi ao próprio Tribunal, ou seja, o direito de punir coincide com o poder judicial de condenar o culpado e de executar a pena. A concepção da pretensão punitiva, segundo o mestre, desconhece que o Estado realiza no processo o seu direito de punir não como parte, mas como juiz.
} 
Ocorre que essa pretensão punitiva se coloca em tensão com outro direito subjetivo público, de titularidade da pessoa a quem se imputa o cometimento do ilícito penal, que é o direito de liberdade. Destarte, na seara processual penal, compete à tutela cognitiva formular a norma jurídica concreta para o escopo de resolver sobre a prevalência, no caso, do interesse estatal de punir ou do oposto interesse na preservação da liberdade do imputado. O processo penal é instituído, preferentemente, para verificar se determinado fato aconteceu e é delituoso e se o imputado é o responsável pela prática dele. Preferentemente, porque a instauração do processo pode se subordinar não à comprovação da pretensão punitiva, mas do direito de liberdade (SILVA, 1957, p. 90). Portanto, a tutela jurisdicional penal cognitiva pode se manifestar normalmente nas espécies condenatória, declaratória e constitutiva. Os mais emblemáticos e usualmente citados exemplos de demandas penais voltadas à obtenção de tutela cognitiva não-condenatória, em prol do jus libertatis, são o habeas corpus e a revisão criminal (TUCCI, 2002, p. 103-104).

O habeas corpus pode ter feição declaratória, por exemplo, quando intenta declarar a cessação do motivo que autorizou a prática de algum ato coativo contra o paciente, notadamente as medidas cautelares pessoais, ou declarar a inexistência da relação jurídicopenal, em razão da extinção da punibilidade do agente (art. 648, incs. IV e VII, do CPP). De outro ângulo, o remédio tem natureza constitutiva negativa quando se volta à anulação de um processo penal condenatório viciado (art. 648, inc. VI, do CPP). Ademais, vale-se ele da técnica mandamental para a expedita realização da tutela ao direito de liberdade (GRINOVER; FERNANDES; GOMES FILHO, 1999b, p. 346). ${ }^{16}$

Quanto à revisão criminal, a depender da pretensão deduzida, pode outorgar tutela apenas desconstitutiva (juízo rescindente), quando se restringir à anulação da sentença penal condenatória ou do processo em que proferida (art. 626, caput, in fine, do CPP), ou tutela objetivamente complexa, desconstitutiva e declaratória (juízos rescindente e rescisório), quando visar à absolvição do sentenciado, à alteração da classificação da infração ou à redução da pena imposta (art. 626, caput, do CPP) (GRINOVER; FERNANDES; GOMES FILHO, 1999b, p. 329). ${ }^{17}$

No tocante ao processo penal de conhecimento condenatório, que interessa mais de perto a este trabalho, leciona Afrânio Silva Jardim (2001, p. 17) que, na verdade, a

\footnotetext{
${ }^{16}$ Sustentando uma maior amplitude para o cabimento de ação declaratória na Justiça Penal, v. CARVALHO, 2001.

${ }^{17} \mathrm{O}$ autor da revisão criminal pode cumular também pedido sucessivo de tutela condenatória, dirigida contra o Estado, para a fixação de justa indenização pelos prejuízos sofridos decorrentes do erro judiciário, no caso de procedência do pleito revisional (art. 630 do CPP).
} 
"processualização" do poder-dever de punir do Estado atende aos sempre presentes anseios de proteger a liberdade individual frente aos possíveis abusos dos órgãos persecutórios penais. Também a tutela da liberdade é um meio de o Estado atingir o seu fim último, qual seja, o bem comum das pessoas que vivem em sociedade. Trata-se de uma posição de compromisso, pois, se é verdade que o Estado deve punir aqueles que delinquiram, não menos verdade é que deve fazê-lo de forma justa e segura. Sendo a liberdade um direito cuja fruição deve ser assegurada pelo Poder Público no limite do interesse coletivo, tornou-se imperioso judicializar o jus puniendi do Estado, de modo que se pudessem utilizar métodos capazes de levar ao conhecimento de um julgador imparcial o que ocorreu no mundo fático. ${ }^{18}$

Por conseguinte, ainda com o ilustre processualista carioca (JARDIM, 2001, p. 18), ao exigir que a pretensão punitiva seja submetida ao crivo processual, o Estado de Direito fez uma sábia opção em prol da segurança e da justiça. Induvidosamente, seria mais eficaz a repressão penal se a pena fosse aplicada administrativamente. Entretanto, dúvida também não há de que, se assim fosse, restaria instaurado o império do medo e da prepotência. Assume-se, deliberadamente, o risco concreto de absolver alguns criminosos, mas não se assume o risco de condenar inocentes. Sob certo aspecto, o processo penal condenatório representa mais uma forma de autolimitação do Estado do que um instrumento destinado à persecução criminal.

Bem elucida Gustavo Badaró (2000, p. 76-77) que o conceito de pretensão punitiva se refere à pretensão material, e não processual, esta sim objeto do processo penal condenatório. Vale dizer, é uma pretensão que já existe antes do processo e que será seu substrato, mas que de nenhuma forma se identifica com a pretensão processual, veiculada através da demanda ou acusação. Assim, essa pretensão material, anterior e extraprocessual, ingressará no processo condenatório, sendo a razão ou motivo dele. No processo, porém, o que existe é a pretensão processual, embora esta apresente como parte de seu fundamento os elementos que compunham a pretensão material. ${ }^{19}$

Nessa linha, cumpre esclarecer que a punibilidade, a qual em atividade se traduz na pretensão punitiva, pertence como categoria jurídica aos domínios do Direito Penal substancial, e, via de regra, surge desde o momento em que se comete uma infração penal, isto é, um fato típico, ilícito e culpável. A punibilidade não integra o conceito analítico de delito,

\footnotetext{
${ }^{18}$ Como acentua Gustavo Badaró (2003, p. 206), a necessidade do contraditório como meio mais eficiente para a descoberta da verdade exigiu que o processo penal condenatório fosse um processo necessário, impondo o nulla poena sine judicio.

${ }^{19}$ Anote-se, porém, que Rogério Lauria Tucci (2000, p. 34-35, 180-181), na esteira do pensamento do lusitano Manoel Cavaleiro Ferreira, refuta a valia do conceito de pretensão no processo penal, porquanto, a seu ver, este se destina à definição de um conflito de interesses públicos entendido objetivamente, e por conseguinte marcado pela impessoalidade, e não de uma contraposição subjetiva de pretensões.
} 
tratando-se da possibilidade de impor ao sujeito ativo a respectiva consequência jurídica. É um posterius relativamente à infração penal, da qual se origina. Por vezes, subordina-se ao implemento de uma condição extrínseca ao delito (condição objetiva de punibilidade), ao passo que em outras o agente está isento de pena em razão de uma condição de natureza pessoal (escusa absolutória). Por fim, há casos em que a punibilidade, embora inicialmente configurada, vem a ser depois declarada extinta (causas de extinção da punibilidade) (PRADO, 2006, v. 1, p. 705). ${ }^{20}$

A constatação da punibilidade, nesse aspecto material e desde logo, antes mesmo do desenrolar de toda a atividade processual instrutória e cognitiva, seria tarefa acessível apenas a um observador onipresente e onisciente. Por isso, na perspectiva problemática empíricoprocessual da persecução criminal, toma-se como ponto de partida uma punibilidade meramente hipotética, apta a fundamentar a pretensão processual deduzida na acusação, cujos pressupostos (existência e autoria do fato, tipicidade, ilicitude e culpabilidade) terão sua ocorrência verificada sob o crivo do contraditório. ${ }^{21}$

Abordadas suficientemente as premissas necessárias, passaremos ao derradeiro e principal tópico do trabalho, qual seja, a análise das sentenças previstas na estrutura do processo penal de conhecimento condenatório, à luz da classificação ternária da tutela jurisdicional cognitiva.

\section{PROCESSO PENAL DE CONHECIMENTO CONDENATÓRIO: ANÁLISE DA TIPOLOGIA DE SENTENÇAS JUDICIAIS}

É cediço que, sob a égide da ciência processual contemporânea, as sentenças judiciais podem ser distinguidas em definitivas ou de mérito e terminativas. A sentença definitiva ou de mérito é o ponto culminante do módulo processual de conhecimento; é o ato jurisdicional mediante o qual se formula a norma jurídica concreta definidora da situação controvertida submetida à apreciação do Poder Judiciário, cumprindo efetivamente e de forma completa a prestação da tutela cognitiva, seja ao autor, quando reconhecida a procedência do seu pedido,

\footnotetext{
${ }^{20}$ Como leciona Érika Mendes de Carvalho (2008, p. 62), as categorias que compõem o conceito de delito são imprescindíveis para a imposição de uma pena. Ao contrário da punibilidade, esses elementos devem estar sempre presentes para a aplicação de uma pena, sem exceção. Assim, para o apenamento, é indispensável a presença de uma ação ou omissão típica, antijurídica e culpável, embora em ocasiões excepcionais se exija, como pressuposto da imposição da pena alheio ao delito, a concorrência de uma condição objetiva de punibilidade ou a ausência de uma escusa absolutória.

${ }^{21}$ No expressivo magistério de Jorge A. Clariá Olmedo (1998, t. 1, p. 40): "El derecho procesal penal asume la realidad delictiva captada por el derecho material sólo como posibilidad o existencia de futuro: hipótesis a concretar conforme al derecho. Esto demuestra correlación entre lo sustantivo y lo procesal pero al mismo tiempo implica independencia en cuanto al sentido y fines de la normación".
} 
seja ao réu, quando declarada a improcedência. De outro lado, sentença terminativa é a que, expressando juízo negativo de admissibilidade da demanda, motivado pela falta de condição para o regular exercício do direito de ação, de pressuposto processual ou, eventualmente, de um outro requisito procedimental imposto pela lei, determina a extinção do processo sem resolução de mérito. $\mathrm{O}$ principal traço diferenciador entre ambas está na aptidão para formar a coisa julgada material, presente na primeira espécie e ausente na segunda. ${ }^{22}$

Na sistemática instituída pelo Código de Processo Penal, todavia, designam-se por sentenças, no processo penal de conhecimento condenatório, somente os atos jurisdicionais decisórios que, após cognição judicial suficientemente profunda das questões de fato e de direito, encerram o procedimento desenvolvido em primeiro grau de jurisdição, bem como, eventualmente, o próprio processo, solucionando ou não o meritum causae. ${ }^{23} \mathrm{O}$ processo penal condenatório de primeira instância, destarte, conhece ex vi legis como sentenças a de impronúncia, a absolutória (doutrinariamente dividida em própria e imprópria) e a condenatória. ${ }^{24}$ Todas devem observar os requisitos estruturais contemplados no art. 381.

A impronúncia, atualmente insculpida no art. 414 do CPP - art. 409 na redação original do diploma, antes da reforma operada pela Lei 11.689/2008 -, é uma das vias possíveis ao final da primeira etapa do procedimento especial dos crimes de competência do Tribunal do Júri, a

\footnotetext{
${ }^{22}$ Vale lembrar que, havendo extinção do processo sem resolução de mérito, presta-se tutela jurisdicional em favor do demandado, ainda que de menor intensidade, cf. DINAMARCO, 1996, p. 29; e COSTA, 2005, p. 123-137. Ademais, as sentenças que rejeitam o pedido do autor sempre prestam tutela declaratória negativa em prol do réu, à exceção da pretensão deduzida em ação declaratória negativa, cuja improcedência gera tutela declaratória positiva para o demandado, cf. CINTRA; GRINOVER; DINAMARCO, 2010, p. 329.

${ }^{23}$ Por motivo de facilitação sistemática e expositiva, serão abordadas as sentenças judiciais tais como previstas nos procedimentos em primeiro grau de jurisdição. É óbvio que os acórdãos dos tribunais, proferidos no exercício de competência recursal ou originária, poderão ter os mesmos conteúdos delas, eis por que as referências às decisões dos pretórios seguirão implícitas e deverão ser subentendidas no decorrer do texto.

${ }^{24}$ Vê-se que o CPP, de forma bastante confusa e diferentemente do Código de Processo Civil, não considera sentenças todas as decisões terminativas, a exemplo de como trata a rejeição da denúncia ou da queixa (art. 395). $\mathrm{O}$ art. 800, inc. I, do CPP reserva a esse pronunciamento judicial a natureza de decisão interlocutória mista, à qual a doutrina costuma somar o adjetivo terminativa, cf. MARQUES, 1961, v. 2, p. 82-83; TOURINHO FILHO, 1997, v. 4, p. 213-214; e GRINOVER; FERNANDES; GOMES FILHO, 1999b, p. 60. No modelo de justiça penal consensual estabelecido pela Lei 9.099/1995, são consideradas sentenças também as decisões que homologam a composição civil entre o ofendido e o autor do fato (art. 74, caput) e a transação penal entre o Ministério Público e o indigitado infrator (art. 76, § $5^{\circ}$ ). A sentença homologatória da transação penal, de acordo com respeitável posicionamento doutrinário, constitui uma classe à parte, não se caracterizando como condenatória (própria ou imprópria) ou absolutória. Ela não indica acolhimento nem desacolhimento do pedido do autor, que sequer foi formulado, mas compõe a controvérsia de acordo com a vontade dos envolvidos, constituindo título executivo judicial. Nesse sentido, v. GRINOVER et al, 2000, p. 153-155. Todavia, há quem sustente que aquela sentença é equiparável à de mérito e tem eficácia condenatória, cf. KARAM, 2004, p. 98-99. O presente estudo se limita à análise das sentenças judiciais proferidas no processo penal de conhecimento condenatório dito clássico ou conflitivo, razão por que a sentença homologatória da transação penal é propositalmente deixada de fora do elenco selecionado para exame.
} 
da instrução preliminar, também conhecida por judicium accusationis. Esta fase tem por finalidade precípua efetuar o controle da viabilidade da acusação, em acepção mais ampla que a da singela admissibilidade. Por viabilidade queremos significar sobretudo a fiscalização qualitativa da acusação quanto à probabilidade de procedência, visto que, estando o julgamento pelo Júri inserido na Lei Maior como um direito fundamental individual (art. $5^{\circ}$, inc. XXXVIII), seria absurdo contrassenso submeter o réu aos riscos de um veredito condenatório, proferido por íntima convicção pelos jurados, diante de acusação temerária ou pouco respaldada (GRECO FILHO, 1998, p. 416). ${ }^{25}$

Preconiza o caput do art. 414 que o juiz, não se convencendo da materialidade do fato ou da existência de indícios suficientes de autoria ou de participação, fundamentadamente, impronunciará o acusado, decretando assim o término antecipado do processo e barrando o envio da causa à apreciação do Conselho de Sentença. Por sua vez, o parágrafo único estabelece que, enquanto não ocorrer a extinção da punibilidade, poderá ser formulada nova denúncia ou queixa, se houver prova nova.

A natureza jurídica de sentença da impronúncia é expressamente reconhecida pelo art.

\begin{abstract}
${ }^{25}$ Assim, parece-nos que a máxima in dubio pro societate, que alegadamente norteia o final da instrução preliminar, há que ser seriamente repensada, tomando por base a ideia dos modelos de constatação ou standards de prova (TARUFFO, 2005; KNIJNIK, 2007, p. 15 ss). A expressão deve ser compreendida não no sentido de bastar, para o impulso à fase de julgamento em plenário, a verossimilhança da imputação, própria do juízo de recebimento da denúncia ou da queixa - pois desta forma a instrução preliminar seria de todo despicienda -, mas tampouco no sentido de exigir a prova além da dúvida razoável necessária para o juízo condenatório penal, ou mesmo a prova clara e convincente necessária, por exemplo, para o juízo condenatório em demanda de responsabilização por ato de improbidade administrativa. Por envolver atividade instrutória e cognitiva relevante e aprofundada, porém ainda não exauriente - dada a estrutura ritual bifásica e a possibilidade de continuidade e complementação da produção probatória - , o modelo de constatação mínimo adequado quanto à autoria ou a participação do réu, para a conclusão do judicium accusationis com a sua pronúncia ou impronúncia, deve ser o de preponderância das provas. Por conseguinte, o raciocínio a ser empregado é o de verificar se o conjunto probatório reunido aponta prevalentemente para a culpabilidade do acusado, tal como afirmada na denúncia ou na queixa. Observe-se que, no tocante à materialidade do fato criminoso, o próprio art. 413, caput, do CPP exige como standard probatório mínimo a prova clara e convincente, não impondo desde logo que a comprovação ocorra além da dúvida razoável. Nestes moldes merece ser interpretada - conforme a Constituição e as características teleológicas e processuais da fase instrutória prévia - a dicção "materialidade do fato e indícios suficientes de autoria ou participação", trazida nos arts. 413, caput, e 414, caput, ambos do CPP. Resultando positiva aquela apreciação, terá lugar a decisão de pronúncia, que encaminhará o feito ao juiz natural. Resultando negativa, terá lugar a sentença de impronúncia, que fará cessar o curso processual. De outro lado, havendo prova clara e convincente sobre a inexistência do fato ou a desvinculação pessoal do acusado, bem assim sobre a presença de causa excludente da tipicidade, da ilicitude ou da culpabilidade, caberá ao magistrado absolver sumariamente o réu (art. 415 do CPP), ao passo que, também diante de prova clara e convincente e concluindo o julgador, na operação intelectiva de enquadramento típico, pela ocorrência de crime diverso do doloso contra a vida, deverá promover a desclassificação e encaminhar os autos ao órgão competente para prosseguir na análise do caso penal, se não o for (art. 419 do CPP). É compreensível, no momento procedimental em apreço, que o standard probatório precise ser algo mais alto que o critério da preponderância para justificar a abreviação do processo e a imediata absolvição do imputado ou desclassificação do delito, a fim de não excluir açodada e indevidamente do Tribunal do Júri o julgamento da causa, após o esgotamento das oportunidades instrutórias.
\end{abstract}


416 do CPP, na redação conferida pela Lei 11.689/2008, que assim a nomina e prevê para sua impugnação o recurso de apelação. Ademais, costuma ser atribuído à decisão em tela caráter terminativo, uma vez que extingue o processo penal condenatório de rito especial sem resolução de mérito, ensejando a formação apenas de coisa julgada formal, o que explica a possibilidade de repropositura da demanda penal, desde que alicerçada em novos elementos de convicção em desfavor do imputado (MARQUES, 1962, v. 3, p. 198-199; GRINOVER; FERNANDES; GOMES FILHO, 1999b, p. 60; BADARÓ, 2008, p. 87; GOMES; CUNHA; PINTO, 2008, p. 69-70; FEITOZA, 2008, p. 114-116).

Trata-se de hipótese excepcional na qual o ordenamento jurídico autoriza o julgador a proferir o non liquet, uma vez que não julga nem procedente - o que, inclusive, não poderia fazer, por ser desprovido da competência para tanto -, nem improcedente a pretensão processual, limitando-se a declarar que ela não logrou reunir supedâneo empírico para prosperar e a lhe trancar o acesso à fase seguinte. ${ }^{26}$ Destarte, sopesando os interesses em jogo de um lado, o risco para o imputado de uma condenação injusta, sem respaldo probatório suficiente, e de outro, a eficiência na persecução criminal dos delitos contra a vida, que vulneram bem jurídico de extrema significância jurídico-social -, o sistema normativo impede desde $\log$ o o prosseguimento do processo penal, contudo, de modo a não tolher peremptoriamente o interesse repressivo estatal, permite a sua renovação diante de novas provas.

Por uma opção político-legislativa, o judicium accusationis se vale da técnica processual da cognição plena e exauriente secundum eventum probationis, mediante a qual, conforme ensina Kazuo Watanabe (1999, p. 19), a decisão da questão, ou mesmo do thema decidendum, está condicionada à profundidade da cognição que o magistrado conseguir eventualmente estabelecer com base nas provas existentes nos autos. À conclusão de insuficiência probatória, a questão não é decidida, ou o objeto do processo é decidido sem caráter de definitividade, não alcançando, bem por isso, a autoridade de coisa julgada material. $^{27}$

Não obstante, a sentença de impronúncia presta ao réu tutela jurisdicional cognitiva declaratória negativa concernente à viabilidade da acusação, dotada de certo grau de estabilidade, livrando-o do processo criminal e do julgamento pelo Tribunal do Júri, pelo

\footnotetext{
${ }^{26}$ De acordo com Camilo Zufelato (2011, p. 289), o non liquet consiste em uma técnica segundo a qual deixa de ocorrer o julgamento do pedido, em razão da incerteza do juiz, gerada pela falta de convicção decorrente da deficiência de provas.
} 
menos se e enquanto não sobrevier prova nova, nos moldes do art. 414, par. ún., do CPP. ${ }^{28-29}$

Passando às sentenças penais absolutórias, é entendimento corrente que elas se dividem em próprias e impróprias. Ambas as espécies são, inegavelmente, sentenças de mérito ou definitivas, já que dão resposta jurisdicional à pretensão processual deduzida na acusação e são aptas a transitar materialmente em julgado. Ademais, a disciplina fundamental delas é trazida no art. 386 do CPP, sem prejuízo dos arts. 397 e 415, que cuidam da absolvição sumária, respectivamente nos procedimentos comum e especial dos crimes de competência do Tribunal do Júri, e reprisam a maioria das hipóteses previstas no art. 386 (MARQUES, 1962, v. 3, p. 35 40; TOURINHO FILHO, 1997, v. 4, p. 215). ${ }^{30}$

A sentença penal absolutória própria corresponde ao julgamento de total improcedência da pretensão processual consubstanciada na denúncia ou na queixa, acarretando a completa liberação da esfera jurídica do imputado de qualquer gravame substancial - e também instrumental, na forma do art. 386, par. ún., incs. I e II.

Conforme o art. 386 do CPP, o juiz absolverá o réu, mencionando a causa na parte dispositiva da sentença, se reconhecer: estar provada a inexistência do fato (inc. I); não haver prova da existência do fato (inc. II); não constituir o fato infração penal (inc. III); estar provado que o réu não concorreu para a infração penal (inc. IV); não existir prova de ter o réu concorrido para a infração penal (inc. V); existirem circunstâncias que excluam o crime ou isentem o réu de pena (arts. 20, 21, 22, 23, 26 e 28, $\S 1^{\circ}$, todos do Código Penal), ou mesmo se

\footnotetext{
${ }^{27}$ Sobre as peculiaridades do emprego dessa técnica na fase da instrução preliminar do rito especial das causas de competência do Tribunal do Júri e os modelos de constatação exigidos para cada decisão, v. nota 24.

${ }^{28}$ Por "novas provas" se devem entender aquelas não constantes do processo anterior e que possam mudar a conviç̧ão do juiz sobre a autoria ou a materialidade (BADARÓ, 2008, p. 87). Vicente Greco Filho (1998, p. 415) sustenta que a disposição do CPP seria inconstitucional, por violar o princípio de liberdade de que ninguém pode ser processado duas vezes pelo mesmo fato. Embora não vislumbremos, como o mestre, sede constitucional para tal proibição, é certo que ela encontra inegável assento convencional, no art. 8.4 da Convenção Americana dos Direitos Humanos, que integra o ordenamento jurídico brasileiro, guardando por isso, na esteira da jurisprudência recente do Supremo Tribunal Federal, status normativo supralegal. Ainda assim, cremos que o art. 414, par. ún., do CPP não colide com a regra convencional. Com efeito, o mencionado art. 8.4 tem a seguinte redação: "O acusado absolvido por sentença passada em julgado não poderá ser submetido a novo processo pelos mesmos fatos" (grifo nosso). Vale repetir que a sentença de impronúncia, conforme as razões alinhavadas no texto, constitui uma sentença terminativa, que não resolve o meritum causae. Logo, não incide na apontada vedação de dupla persecução penal, que exige uma vera, própria e prévia absolvição, pelo mérito.

${ }^{29}$ Mais uma vez, registre-se que a sentença terminativa presta tutela jurisdicional em favor do demandado, ainda que de menor intensidade, cf. DINAMARCO, 1996, p. 29; e COSTA, 2005, p. 123-137. Outrossim, vale consignar que é reconhecida para as decisões que traduzam juízo negativo de admissibilidade natureza essencialmente declaratória negativa, cf. MARQUES, 1962, v. 3, p. 30; e GRINOVER; FERNANDES; GOMES FILHO, 1999b, p. 70, o que se aplica de forma idêntica ao que chamamos de juízo de viabilidade.

${ }^{30} \mathrm{O}$ art. 492, inc. II, do CPP, que trata da sentença absolutória ao término do julgamento em plenário no Tribunal do Júri, não consagra peculiaridade digna de nota, além de sua necessária vinculação ao veredito do Conselho de Sentença.
} 
houver fundada dúvida sobre sua existência (inc. VI); ou não existir prova suficiente para a condenação (inc. VII).

Em acréscimo, o art. 397 preconiza que, após o oferecimento da resposta à acusação pelo denunciado, o julgador deverá absolvê-lo sumariamente quando verificar: a existência manifesta de causa excludente da ilicitude do fato (inc. I); a existência manifesta de causa excludente da culpabilidade do agente, salvo inimputabilidade (inc. II); que o fato narrado evidentemente não constitui crime (inc. III); ou que está extinta a punibilidade do agente (inc. IV).

De outro lado, o art. 415, caput, dispõe que o magistrado, fundamentadamente, ao final da etapa da instrução preliminar, absolverá desde logo o acusado quando: provada a inexistência do fato (inc. I); provado não ser ele autor ou partícipe do fato (inc. II); o fato não constituir infração penal (inc. III); ou demonstrada causa de isenção de pena ou de exclusão do crime (inc. IV).

Em todos esses casos, o juiz declara a inexistência da relação jurídico-penal cuja afirmação constituía o embasamento da acusação, seja após o esgotamento da atividade instrutória possível no procedimento (art. 386), seja em momento anterior, mas já constando dos autos elementos de convicção idôneos e suficientes a tanto (arts. 397 e 415). Presta, por conseguinte, tutela jurisdicional cognitiva declaratória negativa em favor do imputado, apta a ganhar a imutabilidade da coisa julgada material (MARQUES, 1962, v. 3, p. 38; TORNAGHI, 1978, v. 4, p. 384; TOURINHO FILHO, 1997, v. 4, p. 215, 255).

A sentença penal absolutória imprópria, ao seu turno, é a que, sem embargo da absolvição, impõe ao réu medida de segurança, ex vi do art. 386, par. ún., inc. III, do CPP, quando reconhecida a sua inimputabilidade em razão de doença mental ou desenvolvimento mental incompleto ou retardado, somada à sua periculosidade. A rigor, de acordo com a doutrina mais atenta, tal decisão tem na verdade natureza condenatória, porquanto nela o julgador aplica providência que, a despeito da finalidade exclusivamente preventiva especial, é uma espécie de sanção penal, abrindo margem à sua execução forçada (MARQUES, 1962, v. 3, p. 39-40; PRADO, 2006, v. 1, p. 690; TOURINHO FILHO, 1997, v. 4, p. 215, 254). De fato, todos os elementos do conceito de condenação que lançamos alhures estão presentes no pronunciamento judicial em apreço: quanto ao conteúdo, há o reconhecimento de uma infração a uma norma jurídico-penal material, qual seja, um injusto penal (fato típico e ilícito), e a fixação concreta da consequência jurídica que o ordenamento lhe comina, justamente a medida de segurança; quanto ao aspecto formal, o comando judicial emergente se traduz em um preceito processual sancionador que absorve e cristaliza aquela sanção penal e, vol.09, n. 03, Rio de Janeiro, 2016. pp. 
simultaneamente, constitui o título executivo, legitimador do emprego da execução forçada para a sua realização; finalmente, no plano eficacial, o ato jurisdicional autoriza e regula a subsequente invasão da esfera jurídica do réu, a prática de atos de coerção e a privação (medida de segurança detentiva) ou restrição (medida de segurança ambulatorial) da sua liberdade para dar efetividade à sanção aplicada, pois ele não a pode cumprir de modo voluntário. Logo, entendemos que o decisum confere inequívoca tutela jurisdicional cognitiva condenatória.

Veja-se que esse foi também o posicionamento esposado pelo Tribunal Superior Eleitoral no bojo do Processo Administrativo n. 19.297, referente a consulta formulada pela Corregedoria Regional Eleitoral do Paraná e encaminhada à Corregedoria-Geral Eleitoral, que ensejou a manifestação da Corte e resultou na edição da Resolução n. 22.193, cuja ementa tem o seguinte teor:

Resolução n. 22.193: Medida de segurança. Suspensão de direitos políticos. Natureza condenatória. Possibilidade. Não obstante tratar-se de sentença absolutória imprópria, a decisão que impõe medida de segurança ostenta natureza condenatória, atribuindo sanção penal, razão por que enseja suspensão de direitos políticos nos termos do art. 15, III, da Constituição Federal. (Rel. Min. Francisco Peçanha Martins, j. em 11.04.2006, p. no DJ de 09.06.2006)

O TSE, como visto, reconheceu-lhe a feição condenatória e disso extraiu o cabimento da consequência extrapenal prevista no art. 15, inc. III, da CF/1988, isto é, a suspensão dos direitos políticos do condenado criminalmente em caráter irrecorrível, enquanto perdurarem os efeitos penais da condenação, diga-se, o cumprimento da pena ou, no caso, da medida de segurança.

Por derradeiro, tratemos da sentença penal condenatória, a qual, na sistemática do Código de Processo Penal, coincidente em tudo com o magistério doutrinário, é aquela que julga procedente, no todo ou em parte, a pretensão processual deduzida na acusação, infligindo ao réu uma pena. Seu regramento fundamental é trazido no art. 387, que fixa os requisitos a serem observados pelo julgador na dosimetria penal e na determinação do regime inicial para a sanção corporal (incs. I, II e III e $\S 2^{\circ}$ ), na concretização da obrigação de reparar o dano ex delicto (inc. IV), na aplicação de medidas cautelares (inc. V e $\S 1^{\circ}$ ) e na publicidade do decisum (inc. VI). ${ }^{31}$

Soa-nos induvidoso que a sentença condenatória penal envolve o elemento declaratório ínsito em todas as espécies de tutela cognitiva, consistente, aqui, na afirmação da existência da

\footnotetext{
${ }^{31} \mathrm{O}$ art. 492, inc. I, do CPP, que trata da sentença condenatória ao término do julgamento em plenário no Tribunal do Júri, também não consagra peculiaridade digna de nota, além de sua necessária vinculação ao veredito do Conselho de Sentença.
} 
relação jurídico-penal, porquanto comprovados satisfatoriamente os pressupostos substanciais da punibilidade hipotética que fundamentou a pretensão processual, vale dizer, a prática de um fato típico, ilícito e culpável ao seu autor ou partícipe, que dá causa ao nascimento da punibilidade real, concreta e efetiva (aspecto estático), convertida em atividade na pretensão punitiva (aspecto dinâmico). A condenação penal implica juízo histórico afirmativo: o fato asseverado pela acusação, ou uma parte dele, existe; foi perpetrado pelo réu; transparece o elemento subjetivo (dolo ou culpa); reúnem-se eventuais condições de punibilidade. Não ocorre automaticamente um acertamento negativo sobre as causas descriminantes ou exculpantes (visto que não são elementos negativos do tipo penal incriminador), que deverão ser decididas como questões de mérito apenas se houverem sido, de qualquer modo, aventadas no processo (CORDERO, 2006, p. 1.004; MARQUES, 1962, v. 3, p. 47-48; PONTES DE MIRANDA, 1974, t. 5, p. 298).

Parece-nos inequívoco, ainda, posto o conceito de condenação que preferimos, já frisado à saciedade, que a inflição da pena, seja ela privativa de liberdade, restritiva de direitos ou pecuniária, manifesta sempre e tipicamente um ato de tutela jurisdicional cognitiva condenatória, definindo in concreto a repercussão sancionadora que o transgressor da norma penal haverá que sofrer em decorrência de sua conduta e fazendo vigorar para o caso as forças latentes da ordem jurídica. Ademais, a escolha e a mensuração da pena não alteram a natureza condenatória dessa sentença penal, como também na esfera cível a delimitação e a quantificação do dano não têm o condão de transformar em uma sentença constitutiva a sentença que condena o demandado ao ressarcimento (MARQUES, 1961, v. 2, p. 39-40; MARQUES, 1962, v. 3, p. 47-48; CINTRA; DINAMARCO; GRINOVER, 2010, p. 330; GOLDSCHMIDT, 2002, p. 29). ${ }^{32-33}$

\footnotetext{
${ }^{32}$ Registrem-se, contudo, as opiniões divergentes de Elio Fazzalari e Guido Roque Jacob, cada qual com seus próprios e judiciosos argumentos. Para Elio Fazzalari (2006, p. 454-455), só há verdadeira condenação quando o comando emergente da sentença tenha conteúdo igual em relação àquele da lei substancial transgredida. Logo, de acordo com o mestre italiano, a sentença de procedência do juiz penal é enquadrada, mais do que entre as sentenças condenatórias, entre as sentenças constitutivas, pois ela não repete o comando da lei substancial penal (proibição ou mandado, já necessariamente infringido), mas sim cria uma situação de conteúdo novo, impondo ao Estado prender o condenado, e a este pagar a pena pecuniária. Já Guido Roque Jacob (1979, p. 414-415) parte da premissa de que o direito estatal de punir o infrator da lei penal é um direito subjetivo público potestativo e que, portanto, a sentença que julga procedente a acusação tem o efeito necessário e constante de alterar o status libertatis do imputado, criando o status poenalis ou criminalis, tratando-se, por isso, de uma sentença constitutiva. Sobre a concepção de Elio Fazzalari, fica claro que o conceito de condenação que encampa é diverso do sustentado neste artigo, o que em consequência leva a conclusão diferente, porém absolutamente coerente e lógica com o ponto de partida do raciocínio. Quanto à posição de Guido Jacob, pensamos ter cabimento a advertência de James Goldschmidt (2002, p. 29), segundo quem o poder de condenar o culpado é um direito potestativo somente no sentido de que se precisa de uma sentença condenatória para que se possa irrogar o mal da pena ao delinquente.
} 
Para além da aplicação da sanção penal, a sentença de procedência da acusação presta tutela cognitiva condenatória em relação à incidência dos chamados efeitos secundários extrapenais genéricos da condenação penal, automáticos, previstos no art. 91 do $\mathrm{CP}$, quais sejam, tornar certa a obrigação de reparar o dano causado pelo crime (inc. I) e a perda em favor da União, ressalvado o direito do lesado ou de terceiro de boa-fé, dos instrumentos do crime, desde que consistam em coisas cujo fabrico, alienação, uso, porte ou detenção constitua fato ilícito, e do produto do crime ou de qualquer bem ou valor que constitua proveito auferido pelo agente com a prática do fato criminoso (inc. II, a e b).

Quanto à reparação do dano ex delicto, o art. 387, inc. IV, do CPP, na redação conferida pela Lei 11.719/2008, preceitua ao magistrado o dever de fixar valor mínimo para ela, considerando os prejuízos sofridos pelo ofendido. De outro lado, o Código de Processo Civil (art. 475-N, inc. II, do CPC/1973; art. 515, inc. VI, do CPC/2015) atribui à sentença penal condenatória transitada em julgado a eficácia de título executivo judicial na esfera cível. ${ }^{34}$ Logo, é nesta que se dará a efetivação da tutela condenatória em causa, através de execução por quantia certa, precedida ou não de liquidação, conforme o interesse do credor em promovê-la pelo valor estipulado no decisum criminal ou por quantum superior.

Acerca da perda em favor da União dos instrumentos, do produto e dos proveitos do crime, a efetivação da tutela condenatória se dá mediante as providências insculpidas no próprio CPP, notadamente nos arts. 122, 124 e 133 e seguintes. Outrossim, a teor do art. 91, §

\footnotetext{
${ }^{33}$ Cintra, Dinamarco e Grinover (2010, p. 331) asseveram que a sentença que aplica ao réu pena de interdição temporária de direitos (art. 47 do $\mathrm{CP}$ ) tem natureza constitutiva. Parece-nos, todavia, que a substituição da pena privativa de liberdade por essa espécie de pena restritiva de direitos não transmuda a natureza condenatória da tutela cognitiva prestada pelo juiz. Primeiramente, porque a interdição de direitos não deixa de caracterizar a invasão da esfera jurídica do condenado e a restrição a um bem jurídico de sua titularidade, componente eficacial próprio da condenação. Em segundo lugar, porque a sanção corporal substituída permanece integra e latente, apenas passando, na estrutura da sentença condenatória, à qualidade de um preceito sancionador subsidiário e sob condição suspensiva (cf. o art. $44, \S 4^{\circ}$, do CP). A situação, aliás, é idêntica nos casos de concessão da suspensão condicional da pena e de imposição das obrigações que a acompanham (art. 77 do CP).

${ }^{34}$ Sobre o fundamento jurídico da configuração do título executivo judicial civil a partir da sentença penal condenatória transitada em julgado, merece ser registrado que a doutrina controverte. Para Araken de Assis (1993, p. 94-95), trata-se de uma eficácia condenatória anexa da condenação criminal, atribuída por força de lei. Alexander dos Santos Macedo (1989, p. 27), ao seu turno, vê no fenômeno processual da influência da sentença penal sobre a jurisdição civil o que chama de eficácia preclusiva pan-processual da coisa julgada material do processo criminal, excepcionalmente conferida pela lei, que impede o juízo cível de decidir novamente mesmo as questões de fato já decididas no âmbito penal. Por fim, de acordo com Ada Pellegrini Grinover (2007, p. 267), a lei opera a ampliação do objeto do processo penal condenatório, para nele incluir o julgamento implícito sobre o dever de reparar o dano ex delicto. E, assim, a coisa julgada passa dos motivos ao próprio dispositivo (implícito) da sentença penal, como resposta à ampliação do objeto do processo, que abrange a condenação ao ressarcimento. Descontadas as claras diferenças entre os argumentos dos autores citados, exsurge claro que o tema não suscita um regime lógico-jurídico único e invariável, antes revelando verdadeira opção político-legislativa conformadora do sistema processual, mutável por isso ao sabor das contingências históricas, geográficas e sociais.
} 
$1^{\circ}$, do CP, incluído pela Lei $12.694 / 2012$, poderá ser decretada a perda de bens ou valores equivalentes ao produto ou proveito do crime, quando estes não forem encontrados ou quando se localizarem no exterior. Nesta hipótese, inclusive, conforme o $\S 2^{\circ}$ do dispositivo, as medidas assecuratórias previstas na legislação processual penal poderiam abranger aqueles bens ou valores equivalentes do investigado ou do acusado, para viabilizar a decretação da perda.

Cumpre salientar que a sentença penal condenatória não se esgota na prestação de tutela cognitiva condenatória, tal qual até aqui abordada. Ela presta também tutela jurisdicional cognitiva constitutiva que opera nos planos penal e extrapenal.

De fato, como efeito secundário penal do julgamento de procedência da acusação, há a desconstituição do status jurídico da "primariedade penal" do condenado, que eventualmente lhe trará uma série de consequências, como a possibilidade de reconhecimento da reincidência (arts. 63 e 64 do CP) e a vedação ou a maior dificuldade de acesso a certos benefícios penais por exemplo, a substituição da pena privativa de liberdade, as alternativas despenalizadoras da transação penal ou da suspensão condicional do processo etc -, no caso de recidiva criminosa (PRADO, 2006, v. 1, p. 672-673).

Ainda, como efeitos secundários extrapenais específicos da condenação penal, que devem ser motivadamente declarados na sentença, prevê o art. 92 do CP: a perda de cargo, função pública ou mandato eletivo, quando aplicada pena privativa de liberdade por tempo igual ou superior a um ano, nos crimes praticados com abuso de poder ou violação de dever para com a Administração Pública, ou quando for aplicada pena privativa de liberdade por tempo superior a quatro anos nos demais casos (inc. I, a e b); a incapacidade para o exercício do poder familiar, tutela ou curatela, nos crimes dolosos, sujeitos à pena de reclusão, cometidos contra filho, tutelado ou curatelado (inc. II); e a inabilitação para dirigir veículo, quando utilizado como meio para a prática de crime doloso (inc. III). Nas situações insculpidas nos incs. I e II, a sentença penal de procedência extingue relações jurídicas existentes - de vínculo funcional ou político entre o agente e o Estado (lato sensu) e de poder familiar, tutela ou curatela do sujeito ativo sobre o sujeito passivo do delito -, ao passo que na situação trazida no inc. III se cria para o condenado a situação jurídica de inabilitação. Nas primeiras, portanto, há tutela desconstitutiva (ou constitutiva negativa), enquanto na última há tutela constitutiva (positiva ou em sentido estrito). Esta, destaque-se, é a única que pode ser revertida por meio da reabilitação criminal (art. 93, par. ún., do CP).

Finalmente, não se pode olvidar que a sentença de procedência da acusação presta tutela constitutiva relativamente ao status civitatis do condenado criminalmente em caráter vol.09, no. 03, Rio de Janeiro, 2016. pp. 
irrecorrível, na forma do art. 15, inc. III, da CF/1988, pois enseja a suspensão dos seus direitos políticos, enquanto perdurarem os efeitos penais da condenação, diga-se, o cumprimento da pena, o que também se aplica, como visto antes, à medida de segurança.

De todo o exposto, conclui-se que a sentença penal condenatória mostra face objetivamente complexa, prestando uma multiplicidade de tutelas condenatórias e constitutivas, que atuam nas esferas penal e extrapenal, em favor do Estado, por seus órgãos do aparato persecutório, da vítima individualizável e da própria coletividade.

Nunca é demais frisar que as apontadas tutelas oriundas da sentença penal de procedência têm as suas eficácias sobrestadas até o trânsito em julgado dela, por imperativo do art. $5^{\circ}$, inc. LVII, da Lei Maior, que consagra entre nós, com extensão ímpar, o princípio da presunção de inocência.

\section{CONCLUSÕES}

À guisa de fechamento, e considerando que os raciocínios foram detalhadamente encadeados no decorrer do trabalho, traz-se a seguir uma síntese das principais conclusões alcançadas, todas elas pertinentes ao aprofundamento do estudo da tutela jurisdicional no campo específico do Direito Processual Penal, mormente sob o viés da análise da tipologia de sentenças judiciais na estrutura do processo penal de conhecimento condenatório brasileiro, à luz da classificação da tutela jurisdicional cognitiva.

Como visto, a ideia de tutela jurisdicional e os seus esquemas classificatórios mais importantes são amplamente acolhidos, na doutrina brasileira, não só no âmbito do Processo Civil, como também no do Processo Penal, tratando-se de temas que verdadeiramente se encontram sob os auspícios da Teoria Geral do Processo.

Quanto à manifestação da tutela jurisdicional cognitiva no âmbito do Direito Processual Penal, em nada se alteram a sua destinação de formular a norma jurídica concreta definidora da situação controvertida submetida à apreciação do Poder Judiciário e a sua atividade predominantemente lógica e retrospectiva de reconstrução histórica dos fatos relevantes e de enquadramento deles em esquemas normativos. A especificação concerne só a esses esquemas normativos, que correspondem a regras e princípios de Direito Penal substancial.

Na sistemática instituída pelo Código de Processo Penal, designam-se por sentenças, no processo penal de conhecimento condenatório, somente os atos jurisdicionais decisórios que, após cognição judicial suficientemente profunda das questões de fato e de direito, 
encerram o procedimento desenvolvido em primeiro grau de jurisdição, bem como, eventualmente, o próprio processo, solucionando ou não o meritum causae. O processo penal condenatório de primeira instância, destarte, conhece ex vi legis como sentenças a de impronúncia, a absolutória (doutrinariamente dividida em própria e imprópria) e a condenatória.

A sentença de impronúncia presta ao réu tutela jurisdicional cognitiva declaratória negativa concernente à viabilidade da acusação, dotada de certo grau de estabilidade, livrandoo do processo criminal e do julgamento pelo Tribunal do Júri, pelo menos se e enquanto não sobrevier prova nova, nos moldes do art. 414, par. ún., do CPP.

Em todas as hipóteses de absolvição própria, o juiz declara a inexistência da relação jurídico-penal cuja afirmação constituía o embasamento da acusação, seja após o esgotamento da atividade instrutória possível no procedimento (art. 386 do CPP), seja em momento anterior, mas já constando dos autos elementos de convicção idôneos e suficientes a tanto (arts. 397 e 415 do CPP), e presta, por conseguinte, tutela jurisdicional cognitiva declaratória negativa em favor do imputado, apta a ganhar a imutabilidade da coisa julgada material.

A rigor, de acordo com a doutrina mais atenta, a chamada absolvição imprópria tem na verdade natureza condenatória, porquanto nela o julgador aplica providência que, a despeito da finalidade exclusivamente preventiva especial, é uma espécie de sanção penal, abrindo margem à sua execução forçada.

A sentença penal condenatória mostra face objetivamente complexa, prestando uma multiplicidade de tutelas condenatórias e constitutivas, que atuam nas esferas penal e extrapenal, em favor do Estado, por seus órgãos do aparato persecutório, da vítima individualizável e da própria coletividade.

O presente artigo, ao fim e ao cabo, mais do que uma tentativa de oferecer respostas às múltiplas e variadas indagações que o tema da tutela jurisdicional no Processo Penal desperta, é um convite a novas perguntas.

\section{JUDICIAL SENTENCES IN CRIMINAL PROSECUTION'S PROCEEDING: ANALYSIS UNDER THE TERNARY CLASSIFICATION OF COGNITIVE JUDICIAL PROTECTION}




\begin{abstract}
This paper analyzes the types of judicial sentences in the Brazilian criminal prosecution's proceeding, under the ternary classification of cognitive judicial protection, seeking to identify the real legal status of the protection given by each one. It departs from theoretical frameworks inspired in the General Theory of Process and preferably uses the dialectic, the systematic, the inductive and the deductive methods. It starts addressing judicial protection and its classification as issues for General Theory of Process. Following, it examines cognitive judicial protection and its manifestation in the cognitive criminal procedure. It continues with the analysis of the judicial decisions defined as sentences provided in the structure of the criminal prosecution's proceeding. It closes with the main conclusions reached in the study of the matter.
\end{abstract}

Keywords: Judicial protection. Classification. Cognitive protection. Criminal prosecution's proceeding. Judicial sentences.

\title{
REFERÊNCIAS BIBLIOGRÁFICAS
}

ASSIS, Araken de. Eficácia civil da sentença penal. São Paulo: Revista dos Tribunais, 1993.

ÁVILA, Humberto. Teoria dos princípios: da definição à aplicação dos princípios jurídicos. 10. ed. São Paulo: Malheiros, 2009.

BADARÓ, Gustavo Henrique Righi Ivahy. Correlação entre acusação e sentença. São Paulo: Revista dos Tribunais, 2000.

Ônus da prova no processo penal. São Paulo: Revista dos Tribunais, 2003.

Tribunal do Júri - Lei 11.689, de 09.06.2008. In: MOURA, Maria Thereza Rocha de Assis (Coord.). As reformas no processo penal: as novas leis de 2008 e os projetos de reforma. São Paulo: Revista dos Tribunais, 2008. p. 50-297.

Medidas cautelares alternativas à prisão preventiva: comentários aos artigos 319-350 do CPP, na redação da Lei 12.403/2011. In: OG FERNANDES, Geraldo (Coord.). Medidas cautelares no processo penal: prisões e suas alternativas: comentários à Lei 12.403, de 04.05.2011. São Paulo: Revista dos Tribunais, 2011. p. 205-297.

Processo penal. Rio de Janeiro: Campus: Elsevier, 2012.

BARBOSA MOREIRA, José Carlos. O novo processo civil brasileiro: exposição sistemática do procedimento. 28. ed. Rio de Janeiro: Forense, 2010.

BEDAQUE, José Roberto dos Santos. Direito e processo: influência do direito material sobre o processo. 2. ed. São Paulo: Malheiros, 1997.

Efetividade do processo e técnica processual. 2. ed. São Paulo: Malheiros, 2007.

BENETI, Sidnei Agostinho. Execução penal. São Paulo: Saraiva, 1996.

BOSCHI, José Antônio Paganella. Persecução penal: o inquérito policial: a ação penal: o Ministério Público. Rio de Janeiro: AIDE, 1987.

BRUNO, Aníbal. Direito penal: parte geral. 2. ed. Rio de Janeiro: Forense, 1959. t. 1. 
BUENO, Cássio Scarpinella. Curso sistematizado de direito processual civil: teoria geral do direito processual civil. 4. ed. São Paulo: Saraiva, 2010. v. 1.

CÂMARA, Alexandre Freitas. Lições de direito processual civil. 18. ed. Rio de Janeiro: Lumen Juris, 2008. v. 1.

CAMBI, Eduardo. Direito constitucional à prova no processo civil. São Paulo: Revista dos Tribunais, 2001.

Neoconstitucionalismo e neoprocessualismo: direitos fundamentais, políticas públicas e protagonismo judiciário. São Paulo: Revista dos Tribunais, 2009.

CARVAlHO, Érika Mendes de. Punibilidade e delito. São Paulo: Revista dos Tribunais, 2008.

CARVALHO, José Orlando Rocha de. A ação declaratória na jurisdição penal. Revista Forense, Rio de Janeiro, n. 356, p. 73-99, jul./ago. 2001.

CARVALHO, Salo de (Coord.). Crítica à execução penal. 2. ed. Rio de Janeiro: Lumen Juris, 2007.

CINTRA, Antonio Carlos de Araújo; GRINOVER, Ada Pellegrini; DINAMARCO, Cândido Rangel. Teoria geral do processo. 26. ed. São Paulo: Revista dos Tribunais, 2010.

CORDERO, Franco. Procedura penale. 8. ed. Milano: Giuffrè, 2006.

COSTA, Susana Henriques. Condições da ação. São Paulo: Quartier Latin, 2005.

DINAMARCO, Cândido Rangel. Tutela jurisdicional. Revista Forense, Rio de Janeiro, v. 92, n. 334, p. 19-41, abr./mai. 1996.

A instrumentalidade do processo. 12. ed. São Paulo: Malheiros, 2005.

FAZZALARI, Elio. Instituições de direito processual. Tradução de Elaine Nassif. Campinas: Bookseller, 2006.

FEITOZA, Denilson. Reforma processual penal: Leis 11.689/2008, 11.690/2008 e 11.719/2008: uma abordagem sistêmica. Niterói, RJ: Impetus, 2008.

FERNANDES, Antonio Scarance. Processo penal constitucional. 4. ed. São Paulo: Revista dos Tribunais, 2005.

Tipicidade e sucedâneos de prova. In: ALMEIDA, José Raul Gavião de; MORAES, Maurício Zanoide de (Coord.). Provas no processo penal: estudo comparado. São Paulo: Saraiva, 2011. p. 13-45.

GOLDSCHMIDT, James. Princípios gerais do processo penal. Tradução de Hiltomar Martins Oliveira. Belo Horizonte: Líder, 2002.

GOMES, Luiz Flávio; CUNHA, Rogério Sanches; PINTO, Ronaldo Batista. Comentários às reformas do Código de Processo Penal e da Lei de Trânsito. São Paulo: Revista dos Tribunais, 2008. 
GOMES FILHO, Antonio Magalhães. Direito à prova no processo penal. São Paulo: Revista dos Tribunais, 1997.

Medidas cautelares e princípios constitucionais: comentários ao art. 282 do CPP, na redação da Lei 12.403/2011. In: OG FERNANDES, Geraldo (Coord.). Medidas cautelares no processo penal: prisões e suas alternativas: comentários à Lei 12.403, de 04.05.2011. São Paulo: Revista dos Tribunais, 2011. p. 15-51.

GRECO FILHO, Vicente. Manual de processo penal. 5. ed. São Paulo: Saraiva, 1998.

GRINOVER, Ada Pellegrini. A eficácia da sentença penal no processo civil (Notas). In: LIEBMAN, Enrico Tullio. Eficácia e autoridade da sentença e outros escritos sobre a coisa julgada. Tradução de Alfredo Buzaid, Benvindo Aires e Ada Pellegrini Grinover. 4. ed. Rio de Janeiro: Forense, 2007. p. 265-273.

GRINOVER, Ada Pellegrini; FERNANDES, Antonio Scarance; GOMES FILHO, Antonio Magalhães. As nulidades no processo penal. 6. ed. São Paulo: Revista dos Tribunais, 1999.

Recursos no processo penal: teoria geral dos recursos, recursos em espécie, ações de impugnação. 2. ed. São Paulo: Revista dos Tribunais, 1999.

GRINOVER, Ada Pellegrini et al. Juizados especiais criminais: comentários à Lei 9.099/95. 3. ed. São Paulo: Revista dos Tribunais, 2000.

JACOB, Guido Roque. O direito penal como direito potestativo e seus reflexos processuais. Revista Forense, Rio de Janeiro, v. 267, p. 410-421, jul./set. 1979.

JARDIM, Afrânio Silva. Ação penal pública: princípio da obrigatoriedade. 4. ed. Rio de Janeiro: Forense, 2001.

Direito processual penal. 11. ed. Rio de Janeiro: Forense, 2005.

KARAM, Maria Lúcia. Juizados especiais criminais: a concretização antecipada do poder de punir. São Paulo: Revista dos Tribunais, 2004.

Liberdade, presunção de inocência e prisões provisórias. Rio de Janeiro: Lumen Juris, 2009.

KNIJNIK, Danilo. A prova nos juízos cível, penal e tributário. Rio de Janeiro: Forense, 2007.

LIEBMAN, Enrico Tullio. Manuale di diritto processuale civile. 4. ed. Milão: Giuffrè, 1980. v. 1.

LIMA, Thadeu Augimeri de Goes. Tutela constitucional do acesso à justiça. Porto Alegre: Núria Fabris, 2013.

LOPES, João Batista. Ação declaratória. 5. ed. São Paulo: Revista dos Tribunais, 2002.

LOZZI, Gilberto. Lezioni di procedura penale. 7. ed. Torino: G. Giappichelli, 2010.

MACEDO, Alexander dos Santos. Da eficácia preclusiva panprocessual dos efeitos civis da sentença penal. Rio de Janeiro: Lumen Juris, 1989. 
MACHADO, Antônio Alberto. Teoria geral do processo penal. São Paulo: Atlas, 2009.

MARINONI, Luiz Guilherme. Novas linhas do processo civil. 2. ed. São Paulo: Malheiros, 1996.

Técnica processual e tutela dos direitos. São Paulo: RT, 2004.

Teoria geral do processo. 3. ed. São Paulo: Revista dos Tribunais, 2008.

MARQUES, José Frederico. Elementos de direito processual penal. 2. ed. Rio de Janeiro: Forense, 1965. v. 1.

Elementos de direito processual penal. Rio de Janeiro: Forense, 1961. v. 2.

Elementos de direito processual penal. Rio de Janeiro: Forense, 1962. v. 3.

Elementos de direito processual penal. Rio de Janeiro: Forense, 1965. v. 4.

MENDES, Gilmar Ferreira. Direitos fundamentais de caráter judicial e garantias constitucionais do processo. In: COELHO, Inocêncio Mártires; BRANCO, Paulo Gustavo Gonet. Curso de direito constitucional. 5. ed. São Paulo: Saraiva, 2010. cap. 6, item V, p. 587-819.

MIRABETE, Julio Fabbrini. Execução penal. 5. ed. São Paulo: Atlas, 1993.

MORAES, Maurício Zanoide de. Interesse e legitimação para recorrer no processo penal brasileiro. São Paulo: Revista dos Tribunais, 2000.

Presunção de inocência no processo penal brasileiro: análise de sua estrutura normativa para a elaboração legislativa e para a decisão judicial. Rio de Janeiro: Lumen Juris, 2010.

NERY JR., Nelson. Princípios do processo civil na Constituição Federal. 7. ed. São Paulo: Revista dos Tribunais, 2002.

OLMEDO, Jorge A. Clariá. Derecho procesal penal. Atualizado por Jorge Eduardo Vázquez Rossi. Buenos Aires: Rubinzal-Culzoni, 1998. t. 1.

PONTES DE MIRANDA, Francisco Cavalcanti. Tratado das ações. São Paulo: Revista dos Tribunais, 1974. t. 5.

PRADO, Luiz Regis. Curso de direito penal brasileiro. 6. ed. São Paulo: Revista dos Tribunais, 2006. v. 1.

RODRIGUES, Horácio Wanderlei; LAMY, Eduardo de Avelar. Teoria geral do processo. 3. ed. Rio de Janeiro: Elsevier, 2012.

ROMEIRO, Jorge Alberto. Da ação penal. 2. ed. Rio de Janeiro: Forense, 1978.

SICA, Heitor Vitor Mendonça. O direito de defesa no processo civil brasileiro: um estudo sobre a posição do réu. São Paulo: Atlas, 2011.

Velhos e novos institutos fundamentais do direito processual civil. In: ZUFELATO, Camilo; YARSHELL, Flávio Luiz (Org.). 40 anos da teoria geral do processo no Brasil: passado, presente e futuro. São Paulo: Malheiros, 2013. p. 430-466.

SILVA, Adhemar Raymundo. Estudos de direito processual penal. Salvador: Aguiar \& vol.09, n. 03, Rio de Janeiro, 2016.pp. 
Souza Ltda., 1957.

TARUFFO, Michele. Tres observaciones sobre "Por qué um estándar de prueba subjetivo y ambiguo no es um estándar", de Larry Laudan. Doxa. Cuadernos de Filosofía del Derecho, Alicante, n. 28, p. 115-126, 2005.

TESHEINER, José Maria Rosa. Elementos para uma teoria geral do processo. São Paulo: Saraiva, 1993.

TONINI, Paolo. A prova no processo penal italiano. Tradução de Alexandra Martins e Daniela Mróz. São Paulo: Revista dos Tribunais, 2002.

TORNAGHI, Helio. Instituições de processo penal. 2. ed. São Paulo: Saraiva, 1978. v. 3, 4. TOURINHO FILHO, Fernando da Costa. Processo penal. 18. ed. São Paulo: Saraiva, 1997. v. 4.

TUCCI, Rogério Lauria. Teoria do direito processual penal: jurisdição, ação e processo penal: (estudo sistemático). São Paulo: Revista dos Tribunais, 2002.

et al. Sistematização das medidas cautelares processuais penais. Revista do advogado, São Paulo, v. XXIV, n. 78, p. 111-122, set. 2004.

WATANABE, Kazuo. Da cognição no processo civil. 2. ed. São Paulo: Central de Publicações Jurídicas; Centro Brasileiro de Estudos e Pesquisas Judiciais, 1999.

ZUFELATO, Camilo. Coisa julgada coletiva. São Paulo: Saraiva, 2011.

Trabalho enviado em 15 de janeiro de 2016.

Aceito em 23 de março de 2016. 